\title{
Understanding Valuing Devices in Tourism through "Place-making"
}

\author{
Vasiliki Baka
}

\begin{abstract}
The paper explores how valuing devices and verification mechanisms such as user-generated content (UGC) websites partake in performing placeness. The findings are based upon a corpus of data including a case study at the offices of the largest user-generated travel website, TripAdvisor, a longitudinal netnographic approach and a conceptual review. Originally inspired by theorists of space we treat places as sites of becoming that are performed through everyday practices. In claiming that places become meaningful only in and through practices we stress the importance of treating rating and ranking mechanisms as generative, rather than merely reductive algorithmically produced representations. By juxtaposing traditional enactments of traveling, we are discussing how placeness has been transformed and how this has fueled a series of further revisions to valuing tourism. We conclude the paper by appreciating the multiplicity of performativity as being implicated in the algorithmic configurations on contemporary valuing devices and enacted as we read, interpret, write, imagine. It is suggested that although earlier valuing devices have evoked place-making in various ways, the rise of UGC websites has converted the travel experience into a constant negotiation process whereby both the value of places and the value of valuing devices are contested.
\end{abstract}

Key words: place-making; performativity; valuing devices; tourism practices; ranking; rating

\section{Introduction}

The paper explores the concept of place-making with the aim of explaining how the rise of emergent valuing devices such as usergenerated content (UGC) websites has influenced tourism practices. Originally inspired by theorists of space, we treat places as sites of becoming that are performed through practices. In claiming that places

Vasiliki Baka, Information Management, IT University of Copenhagen, vasb@itu.dk

(C) 2015 Vasiliki Baka

LiU Electronic Press, DOI 10.3384/VS.2001-5992.1532149

http://valuationstudies.liu.se 
become meaningful only in and through practices we stress the importance of treating rating and ranking mechanisms as generative, rather than merely reductive algorithmically produced representations. The findings are based upon a corpus of data including: a case study at the offices of TripAdvisor, a longitudinal netnographic approach and a conceptual review.

Rating and ranking of hotels and destinations has not only disturbed the established managing practices, but has performative consequences for tourist encounters. The practice of listing places on UGC websites affords an interesting opportunity to examine the nuances of where tourism practices take place and how they are performed differently or not due to the unique configurations of placeness. In so doing, and by juxtaposing traditional enactments of traveling, we are discussing how placeness has been transformed and how this has fueled a series of further revisions to valuation. Therefore part of the aim of this paper is to problematize the notion of place as a sine qua non of what we consider the "tourism product" and to contemplate how it is created and preserved once enacted.

An important distinction to note is between treating spaces from a Cartesian perspective and from a relational ontology. On the one hand, space has been perceived as a fixed territory, distinct from action; as "a container with pregiven attributes frozen in time" (Dodge and Kitchin 2005). On the other hand the relational approach acknowledges the dynamic nature of places, whereby places emerge in and through practice. According to the second stream, "places are like ships, moving around and not necessarily staying in one location" (Sheller and Urry 2006), defined through interrelationships between people and "stuff in motion", known also as the mobility paradigm. The paper draws on the relational approach and aims to interpret travel practices through the theoretical construct of place-making. As we will go on to show, places become where and when instances of traveling are enacted (in the lobby, on line, through magazines, in the imagination); it is the practice of traveling that allows us to involve them all at once and still refer to the same place. In other words, "touristed landscapes are places simultaneously perceived, formed, and reworked by activities of diverse people" (Cartier and Lew 2005, 5).

In our analysis we will use the term place, based on the assumption that it has passed through the notion of space and thus achieved a relational intimacy in practice. This is in line with Augé's idea that "the space could be to the place what the word becomes when it is spoken: grasped in the ambiguity of being accomplished, changed into a term stemming from multiple conventions, uttered as the act of one present (or one time), and modified by the transformation resulting from successive influences" (Augé 1995, 80). Spaces on their way to "places" are articulated and performed by being photographed and touristically consumed, or by being admired in personal travelers' 
diaries and blogs or through daily mass media consumption in magazines, the internet and advertisements—or through a sea pebble secretly taken to be kept as a souvenir.

The question that arises from the convergence of these research interests is formulated as follows: how do valuing devices and verification mechanisms such as UGC websites partake in performing placeness? To this end, we first analyze the development in valuing devices; we travel back to the early valuing devices of the Grand Tour era: "vetturinos" and "bear leaders" and many more valuing devices between then and the UGC era. We nostalgically reintroduce the eighteenth-century "raree showmen", who wandered around with their wooden stereoscopic boxes offering people imaginative travels, and we revisit Urry's tourist gaze. We then shed light on the phenomenon of TripAdvisor as a continuation of previous valuing devices. We conclude the paper by appreciating the role of performativity as being implicated in the algorithmic configurations on TripAdvisor and other travel devices and enacted as we read, interpret, write, imagine. It is suggested that reviews and other popularity-making/co-creation mechanisms become co-constitutive of the multiple identities of the place and hence afford new kinds of place-making that absorb dichotomies such as physical-online and code space.

\section{Theoretical Inspiration: Valuing Value and the Value of Valuing}

"What counts? ... What is valuable, and by what measures?" These questions posed by David Stark $(2009,6)$ have always been questions that we ask in one way or another in the different contexts of our everyday lives. However, Lamont (2012) emphasizes the necessity to revisit what value is and through which mechanisms it is produced: "[U]nderstanding the dynamics that work in favor of, and against, the existence of multiple hierarchies of worth or systems of evaluation (i.e., heterarchies or plurarchies) is more urgent than ever." Although it is admittedly a challenging intellectual endeavor for the various scholarly terrains to commonly agree what constitutes value and worth, what is of importance to this study are exactly the negotiations that happen during any (e)valuation process through rating and ranking mechanisms, on co-creation platforms and other ordering devices.

To this end we discuss in what follows value as a notion that has been approached from various perspectives aiming at better understanding valuation processes with the help of the theoretical constructs of performativity and place-making. Graeber (2001, 1-2), from an anthropological point of view, divides research terrains into three large sets: 


\section{Valuation Studies}

- "Values" perceived in the sociological sense, that is, conceptions of what is ultimately good, proper or desirable in human life

- "Value" in the economic sense, the degree to which objects are desired as measured by how much others are willing to give up to get them

- "Value" in the linguistic sense, which goes back to the structural linguistics of Ferdinand de Saussure, and can be understood as "meaningful difference."

Seminal value-related contributions broadly fit into this typological device. More specifically, Kluckhohn $(1949,358-9)$ introduces "value orientations" as combinations of the desirable and the nature of the world (sociological sense); Evans-Pritchard (1940, 135) perceives values as embodied in words through which they influence behavior (linguistic sense); whereas Sahlins in Culture and Practical Reason $(1976,213)$ emphasizes the economic value as a meaningful distinction (economic sense).

In line with the "sociological sense", Marilyn Strathern refers to value as "the meaning or importance society ascribes to an object" (in Graeber 2001, 39) and in so doing she indicates the importance of making something "visible" when attributing value to it. Science, technology and society (STS) scholars (e.g. Law, Latour, Callon) as well as post-phenomenologists (e.g Don Ihde, Verbeek) emphasized a long time ago the role of instruments as inscription devices that make things (in)visible. Stark $(2009,119)$ in discussing the "accounts of worth in economic life" reminds us that tools count; "tools count insofar as they are a part of situated sociocognitive and sociotechnical networks." This well-grounded and much-discussed assumption has been fundamental in better understanding how calculative practices work and make a difference; or in Lamont's words, in understanding the dynamics in "multiple hierarchies of worth or systems of evaluation." By revisiting tools, formulas, algorithms, media, devices and any instruments we realize how they intervene in a performative way, rather than represent or mediate processes, which brings us to an important theoretical construct of the study: performativity.

\section{Performativity}

Performativity broadly speaking embraces how the efforts to represent a case shape it beyond mere representation and embody what they seek to describe. Originally, performativity theory roots back in "performative utterances", a concept first introduced by Austin. Austin $(1975,5-6)$ describes performative utterances as statements in which in saying something we do something. For instance in saying "I do" in the course of the marriage ceremony or "I name this ship the Queen 
Elizabeth" when smashing the bottle against the stem we do not "describe" or "report" something; there is nothing true or false in those utterances ... "When I say, before the registrar or altar 'I do' I am not reporting on a marriage: I am indulging in it" (ibid).

Moving on to the performativity of practices, Judith Butler is one of the first scholars to extend performativity beyond linguistic acts. She suggests "that a performative is both an agent and a product of the social and political surroundings in which it circulates" (Herman et al. 2006). Butler, having acknowledged Jacques Derrida's notion of repetition, explains that repetition "inheres even within an apparently isolated act or event" (Kirby 2006, 78) and emphasizes that when we perform practices we somehow act or think according to rule-bound settings that preexist and orientate us (with gender and identity being two key illustrations).

What lies beyond linguistic and gender performativity is Lyotard's "principle of optimal performance" which aims to capture the compromise between the "efficient" and the "truth" (Spicer et al. 2009). For Lyotard (1984, 11), performativity is "[T] he optimization of the global relationship between input and output." According to his theory, knowledge produced performatively gains legitimacy not because it is true, but "because it has a technical value associated with producing results" (ibid). This resonates with recent work by Knorr Cetina (2010) who explores the epistemics of information in the context of markets. Using examples of news stories and trading practices, she gives further emphasis to the consequentiality of performativity, framing it as "what happens through our efforts to explain what is happening." This latter concept improves our understanding of performativity in the specific context of UGC by showing how information can initiate responses irrespective of its validity-if we assume there is a mechanism to claim validity.

The markets have provided multiple empirical illustrations for theorists of performativity. MacKenzie highlights the ways in which financial models matter to our understanding of the economy. In particular, he explains how the Black-Scholes-Merton model has been entangled in the agency and structure of trading, rather than merely being an inert tool supporting execution: "the model was a theoretical innovation, not simply an empirical observation ... its role was not always descriptive, but sometimes performative ... An engine not a camera" (MacKenzie 2006, 259). Although the spatial configurations have been broadly overlooked in this context, Stark $(2009,125)$ notes that "trading practices are intimately tied to the deployment of traders and instruments in the room" and he continues by saying that the movement from the shop floor to the new-media space to the trading room was associated with "sites that were generating 'situations' by design.” It is exactly this spatiality, or placeness if you prefer, that this 


\section{Valuation Studies}

study wants to bring to the fore with a focus on how valuing devices perform placeness over time.

\section{Performing Places: "Place-making”}

Places here, contrary to a fixed Cartesian definition that separates them from the people visiting and inhabiting them, are always on the move, in a process of transformation. According to Hannam et al. (2006), "places are not so much fixed but are implicated within complex networks by which 'hosts, guests, buildings, objects and machines' are contingently brought together to produce certain performances in certain places at certain times." But how is place performed?

A helpful illustration to perceive the performativity of place is mapping. The act of drawing maps-the practice of mapping-is a key part of understanding the openness of the phenomena that they aim to capture. A first reading of their purpose would possibly define them as representation tools which aim to orientate their "readers" presupposing an agreed spatial reality. For example the Mercator Projection map was initially designed to facilitate nautical navigation. However, a performative approach "sees mapping as not only taking place in time and space, but also capable of constituting both" (Perkins and Thorns 2001). The performativity of the map lies in its multiple readings and departs from the starting point that we should treat it as a potential option rather than as the only and final representation. As Sullivan $(2011,102)$ notes, "what the map reflects is not this world, but an alternative one, with the map alluding to a world that will exist once the possibilities entailed in the map are performed." It is not the map that makes the place what it is but the place is made once we engage with it in following the map, in ignoring it, etc.

The ways maps - as instruments - are designed and drawn have the power to influence the places that they aim to depict and in a way potentially transform them. For instance the mapping of Africa has been debatable throughout the centuries with disjuncture between the cartography of imperialism in the eighteenth century and the cartography of colonialism in the nineteenth (Stone 1995, 226). Cartography and associated places, apart from acting as a reifying metaphor in the context of performativity, are also constitutive of what tourism and traveling are all about, namely places; ${ }^{1}$ which brings us back to the notion of value and more precisely to valuation processes.

Valuation in this study extends beyond pricing, as the focus is on how signposts of tourism such as hotels come to be desirable and

\footnotetext{
1 The 'place', as we will see, incorporates both the destination and the hotel.
} 
preferable-in the sociological sense à la Graeber. Stark (2011) inspired by Dewey points to this movement away from prices:

\begin{abstract}
Whereas economists have long had time-sensitive data on price movements, we now (or will soon) have alternative (not separate but complementary) databases on the movements of prizing and appraising that register consumer attachments. These "valuemeters" will need new measures and metrics (Latour and Lepinay 2009:16). They can be quantified, but these metrics of personal value judgments need not be expressed in terms of money ... These metrics are valuable precisely because they are metrics that are alternatives to prices.
\end{abstract}

This "soon" of the alternative valuation arrived a long time ago or has always been present camouflaged as trust, reputation and legitimacy. Value that is not economic is also made manifest in Karpik's judgment devices: "networks, appellations, cicerones, rankings, and confluences" (2010, 45-6). Networks are safety mechanisms (personal, practitioners, trade) whose knowledge minimizes uncertainty, appellations are brands, "cicerones" embrace the critics and guides that offer specific evaluations, rankings (either experts or buyers) are hierarchical arrangements and "confluences" designate sales and marketing techniques and channels.

In the context of tourism, Karpik provides examples and refers to official sources of knowledge production that partake in processes of valuation.

The Lonely Planet series is encyclopedic in scope, practical ... and supposes autonomous users. The Literary Guides ... rank cultural curiosities ... [Routard and Knopf] mark trails for exploration, while Michelin's Green Guides ensure the transmission of knowledge about history and civilization. (ibid, 70)

The Michelin Guides, Lonely Planet, Literary Guides and Rough Guides are among the most influential accreditation schemes. Such reputation contests are "social tests of products and organizations" (Rao 1994) that minimize uncertainty and establish organizational standing. Espeland and Sauder (2007) highlight the "reactive" and "self-reinforcing behaviors" that these mechanisms generate: "Reputational metrics and rankings are 'reactive' or performative by generating self-reinforcing behaviors and shifting cognitive frames and values over time." Power et al. (2009) also acknowledge the generativity of rankings when they note that irrespective of whether they are true or not they are social facts that generate actions and reactions.

But why should online ratings and rankings constitute ordering/ judgment devices of a different sort? Mellet et al. (2014) in their study of restaurant review sites as calculative devices describe the production of evaluation and note how these sites are combinations of multiple "judgment devices." This multiplicity in combination with the unique spatial configurations constitute online ranking mechanisms "ordering 


\section{Valuation Studies}

devices" of special interest. Not only because of the unique affordances of the "online" but also because of the associated algorithmic configurations. It is what Gillespie (2014) describes as "the 'networked publics' forged by users and the 'calculated publics' offered by algorithms that further complicates the dynamics of networked sociality." So, algorithmically produced rankings are calculative devices in that they both organize connections, as well as establish the rules according to which these connections are to be organized (Callon and Muniesa 2005).

It is exactly this performative power that we are intrigued to uncover or in other words, what Helgesson and Muniesa (2013) describe as the reordering effects that the outcomes of valuations might have and the certain orders that the making of valuations perform. This study contributes an analysis of algorithmically powered verification processes to existing notions of performativity. As Kjellberg and Mallard (2013) nicely put it: "as world-making and sense-making activities, valuation processes partake in the ontological practices through which human and non-human entities make room for themselves in their environments." We therefore build on this stream of research and respond to Appadurai's open call to take an historical position and follow an object's "life history" as it moves back and forth between different "regimes of value" $(1986,5)$. After presenting the research design we will discuss the "life history" of verification mechanisms and valuing devices in tourism starting from the Grand Tour epoch up to the emergence of UGC and TripAdvisor.

\section{Research Design}

A multilevel methodology has been designed around a case study, a netnographic approach and a conceptual historical review. TripAdvisor as the largest travel UGC website has served as the unit of analysis with multiple identities embracing many groups of interest. A total of 100 semi-structured interviews were conducted comprising: 14 interviews with TripAdvisor at their headquarters in Boston and their European offices in London, 21 interviews with hoteliers, nine interviews with travel professionals, nine interviews at two hotel accreditation agencies and 47 interviews with travelers. All interviews lasted between 44 minutes and $1 \frac{1}{2} 2$ hours, followed a semi-structured format and have been recorded and transcribed.

Because of the intrinsic interplay between on line and physical while studying the device of TripAdvisor, immersion in online communities and UGC has been an important part of the study. Kozinets (2002) proposes an adaptation of virtual ethnography, netnography, as a qualitative research methodology that adapts ethnographic research techniques to study communities that are emerging on line. In this study, netnography has been adopted and instantiated in multiple ways: through being part of the TripAdvisor community; through immersion in a number of online travel communities and interaction with travelers; through communication with hoteliers who either contribute to the TripAdvisor community 
and respond to users' comments or have somehow shown they are engaged with TripAdvisor. Part of the virtual immersion has been the close observation of a number of travel related sites, social media sites and blogs. However, what differentiates netnography from online data collection is the development of relationships with respondents over the course of the study.

The respondents who have been contacted on line include hoteliers, hotel managers and hostel owners and users, members of the TripAdvisor community and travelers and bloggers. Netnographic "moments" as well as physical interviews have been imported into Evernote, a software program that has served as a "camera" where files and snapshots of web pages could be captured and stored. In total 1849 notes have been imported and tagged into the database. The tagging of each note was the initial step of coding followed by a preliminary open coding procedure. After the first stage of coding, a more systematic thematic analysis was conducted. Following AttrideStirling's (2001) coding techniques on how to build thematic networks, we produced four thematic networks with the use of "Inspiration" software. The theme that is the focus of this paper is "how verification mechanisms in travel, as valuing devices, have reconfigured placeness" (see Figure 1). The large corpus of data has helped in understanding the phenomenon under study but the story presented here centers mainly on travelers' accounts.

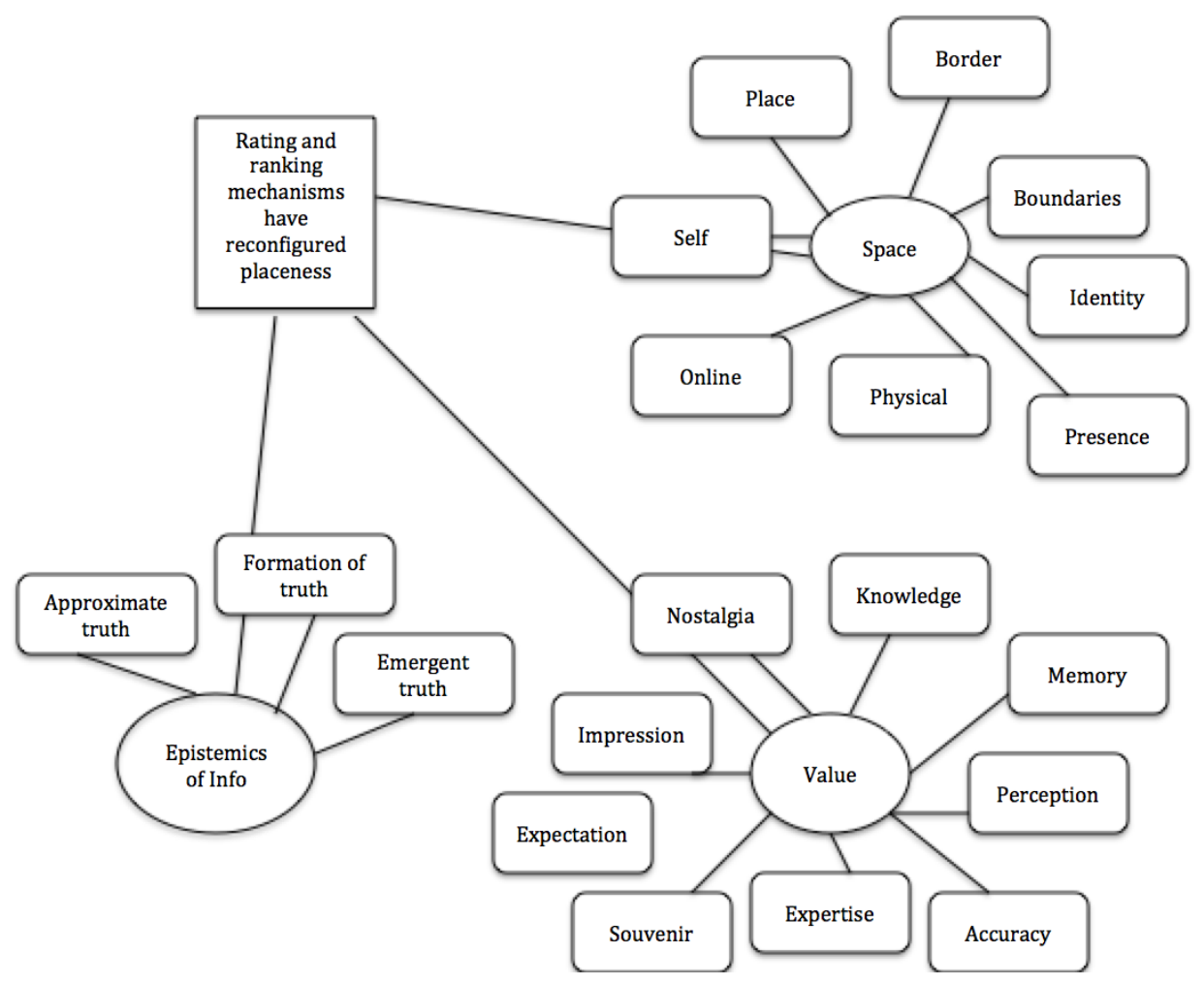

Figure 1 Coding. Theme 1: How verification mechanisms in travel, as valuing devices, have reconfigured placeness 


\section{Valuation Studies}

An integral process in understanding the contemporary phenomenon of UGC has entailed looking at the historicity of tourism and the associated devices over time. Even though archival research methods mainly involve the study of historical documents, they can also be applied to the analysis of digital texts such as electronic databases (Ventresca and Mohr 2002, 848). Aiming at uncovering the evolution of tourism devices, a "conceptual review" has been conducted as a synthesis of relevant conceptual areas that contribute to a better understanding of tourism valuing devices.

To this end, a search has been conducted within the Thomson Reuters (formerly ISI) Web of Science around the term "tourism history." The subject search yielded a total of 818 articles. Of these, 30 were deemed appropriate to be included in the study. The inclusion criteria have been informed by the principle of moving away from quantitative content analysis toward more context-specific analyses such as the coding of semantic grammars (see Ventresca and Mohr 2002, 848). All abstracts have been read looking for references to the themes that have been identified through the netnographic approach. Coding and analysis followed three steps: (i) organization of the studies into categories; (ii) analysis of the narratives within each of the categories; and (iii) synthesis of the story across all included studies (Petticrew and Roberts 2006, 170). In the following section we travel back in time to unpack verification mechanisms before we look at the TripAdvisor phenomenon as it has been experienced through the case study and the netnographic approach.

\section{Verification Mechanisms in Place: Traveling Back in Time}

Since the time of Herodotus, Homer, Pausanias, Chateaubriand and later Grand Tourists the practice of traveling has been associated with seeking the "inner truth" through challenging personal boundaries. As Galani-Moutafi (2000) notes "they [the travelers] were constantly negotiating between the familiar and the unknown, between a here, a there, and an elsewhere." While these negotiations were happening, tourism practices were emerging, such as keeping notes, recommending places, crystallizing time through pictures and other forms, bringing souvenirs back to the homeland and many more.

The practice of the Grand Tour can probably be regarded as "the first extensive tourist movement" (Towner 1985) and the first significant accumulation of written "know how" about travels, through diaries, road books, maps, journals and letters. Young people embarked on the journey primarily to expand their educational horizons and to prepare themselves for prominent positions in society. Between 1661 and 1763 Grand Tourists kept diaries in the format of travelogues with information about the itinerary, the length of stay in centers, the total length of the tour, the method of transport, their 
accommodation and impressions of the areas visited (Towner 1985). Eventually the Grand Tour evolved into what is known as tourism (Brodsky-Porges 1981).

As expected, the Grand Tour era had its own valuation devices, the "vetturini" who acted as travel guides and "guaranteed transport of the student's party and luggage, with pre-determined routing and scheduled stops" (Brodsky-Porges 1981). The vetturini existed alongside "bear leaders" who served as mentors accompanying young students on their journeys. Long after the epoch of the Grand Tour, tourists in the sixteenth and seventeenth centuries choosing accommodation would use the infrastructure available for pilgrims and merchants, mainly consisting of hostels and small inns along the road (Stretton 1924). Interestingly, assessing inns' reputations was an integral part of their travel practice. For instance, through letters later published as travelogues we discover that "The Three Kings" in Milan and the "Star" at Padua were preferred by travelers, as was the Faubourg St Germain in Paris, the Piazza di Spagna in Rome, the "Vaninis" and "Schneiderffs" in Florence and "The Emperor" and "The Red House" in Frankfurt (Towner 1985). These inns achieved reputable standing through the mechanisms in place at that point in history. Let us illustrate how such reputations became public with the use of a travelogue written before 1800 and reproduced recently (courtesy of Google Play). The author, through his reflective narration, recommends the Vaninis in Florence:

If you should meet with anybody going to Florence, do not forget to recommend the Vaninis. We have had no dispute at partying and they behaved so as not only to merit the character of honest, but even something more that is usually meant by that word; theirs is an honourable honesty, a rare quality in hosts. I think we shall have no reason to complain of the people who keep this inn; they are women and seem much humanize and serviable. I break off this letter, as a tolerable supper is just served, and I am a little fatigued with the day's journey. No post quits Sienna to-night for France, so I shall take this letter with me, and continue it as I fee occasion. Sienna is five posts from Florence. (Sharp 1767 [2010])

These personal travel accounts served as an early valuing device in tourism. Other influential sources were "persons held in high-esteem" capable of minimizing uncertainty for tourists who found themselves in unfamiliar places. As Towner (1985) notes, bankers abroad often served as trustworthy sources of information about hotels, servants and places. Towner continues by narrating the role of the British embassy as a more formal authority: "The British embassy would often be the first place a tourist would visit on his arrival in a center. Some representatives like Horace Mann in Florence and William Hamilton in Naples organized assemblies and balls for the tourists, 


\section{Valuation Studies}

where they could meet one another and mix with notable local inhabitants" (Towner 1985). Later we see more organized forms of valuation mechanisms, such as the emergence of published travel guides (in 1839 Karl Baedeker was the first to publish the famous European guide book).

Whereas travelogues presented information in a romantic, autobiographical way, guide books assumed the status of being "factual” (Dann 1999). As Wheeler (1986) puts it, "the subject of the travel book is the essence of 'being there', portraying places, people, events and the journey's progress"; and he goes on, "while vividness is primary, the travel book is also dynamic. The traveler arrives, leaves, keeps moving by boat, camel, horse, truck or on foot. The traveler continually notes the date and how many weeks or months have passed since he left." Moving on to modern printed guide books, the purpose and style of presentation have changed. Comments such as "luxury and elegant simplicity infuse" or "with sophistication befitting ..." accompanied by price estimations and contact details typify the details one can find in travel guides.

As the lodging infrastructure develops, hotel managers attempt to standardize quality and value. The SERVQUAL scale, first introduced in the financial sector, has been adjusted to be used as a valuing device in the hospitality sector. For example, Zeithaml et al. (1990) suggest five factors of service quality: tangibles, reliability, responsiveness, assurance and empathy. Tangibles refer to physical facilities and infrastructure; reliability embraces the ability to provide what has been promised; responsiveness comes as the alertness to react in favor of good service; assurance is the courtesy of members of staff and empathy refers to the personalized and targeted service (Renganathan 2011). Through their inclusion into formal qualifications, the five main categories established were incorporated into the agenda for hoteliers and filtered priorities in what should constitute good service.

The adoption of "best practices" motivated efforts to develop more systematic methods of reputation making and performance monitoring. This included the standardization of different feedback mechanisms including the guest comment card, which still serves as a key management tool for hoteliers (see an example in Figure 2). Found either in the room or at reception, customers can leave their comments by filling in specific categories like quality of food, cleanliness, staff's attitude, etc. The comments are then internally analyzed and reports are produced. 
Not at all satisfied $\leftarrow \rightarrow$ Very satisfied

\begin{tabular}{|lllllll}
\hline 1. & Overall Satisfaction: & ${ }_{1} \square$ & ${ }_{2} \square$ & ${ }_{3} \square$ & ${ }_{4} \square$ & ${ }_{5} \square$ \\
\hline 2. & Value for Money: & ${ }_{1} \square$ & ${ }_{2} \square$ & ${ }_{3} \square$ & ${ }_{4} \square$ & ${ }_{5} \square$ \\
\hline 3. & Front Desk/Reception Service: & ${ }_{1} \square$ & ${ }_{2} \square$ & ${ }_{3} \square$ & ${ }_{4} \square$ & ${ }_{5} \square$ \\
\hline 4. & Cleanliness of Room: & ${ }_{1} \square$ & ${ }_{2} \square$ & ${ }_{3} \square$ & ${ }_{4} \square$ & ${ }_{5} \square$ \\
\hline 5. & Room Maintenance: & ${ }_{1} \square$ & ${ }_{2} \square$ & ${ }_{3} \square$ & ${ }_{4} \square$ & ${ }_{5} \square$ \\
\hline 6. & Breakfast Quality: & ${ }_{1} \square$ & ${ }_{2} \square$ & ${ }_{3} \square$ & ${ }_{4} \square$ & ${ }_{5} \square$ \\
\hline 7. & Restaurant Quality: & $1 \square$ & ${ }_{2} \square$ & ${ }_{3} \square$ & ${ }_{4} \square$ & ${ }_{5} \square$ \\
\hline 8. & Restaurant Service: & $1 \square$ & ${ }_{2} \square$ & ${ }_{3} \square$ & ${ }_{4} \square$ & ${ }_{5} \square$ \\
\hline 9. & Bar Service: & $1 \square$ & ${ }_{2} \square$ & ${ }_{3} \square$ & ${ }_{4} \square$ & ${ }_{5} \square$ \\
\hline 10. & Pool Experience: & $1 \square$ & ${ }_{2} \square$ & ${ }_{3} \square$ & ${ }_{4} \square$ & ${ }_{5} \square$ \\
\hline
\end{tabular}

Was there a particular employee who you feel has delivered particularly outstanding service? Name:

Department:

1. What would you consider to be the best attributes of your experience with us?

2. What would you consider as the areas that should improve for your next visit or which other service would you like to add?

Figure 2. Comment card (kindly provided by a hotel manager who participated in the study)

As part of a sector-wide effort to achieve an agreed set of standards and classification, extensive lists with criteria have been introduced and employed at a national level. VisitBritain, the national tourism agency in the UK, has recently updated the standards hotels should comply with in order to be ranked as one- to five-star premises. The categories include cleanliness, hospitality, bedrooms, bathrooms, food and service (see Figure 3). The exact mechanisms through which a hotel can achieve these percentages are explained in the reports and brochures published by VisitBritain. 


\section{Valuation Studies}

\begin{tabular}{|l|c|c|c|c|c|}
\hline Hotel & 1 Star & 2 Star & 3 Star & 4 Star & 5 Star \\
\hline Overall & $30-46 \%$ & $47-54 \%$ & $55-69 \%$ & $70-84 \%$ & $85-100 \%$ \\
\hline Cleanliness & $40 \%$ & $50 \%$ & $65 \%$ & $75 \%$ & $90 \%$ \\
\hline Hospitality & $30 \%$ & $47 \%$ & $55 \%$ & $70 \%$ & $85 \%$ \\
\hline Bedrooms & $30 \%$ & $47 \%$ & $55 \%$ & $70 \%$ & $85 \%$ \\
\hline Bathrooms & $30 \%$ & $47 \%$ & $55 \%$ & $70 \%$ & $85 \%$ \\
\hline Food & $30 \%$ & $47 \%$ & $55 \%$ & $70 \%$ & $85 \%$ \\
\hline Service & $30 \%$ & $47 \%$ & $55 \%$ & $70 \%$ & $85 \%$ \\
\hline
\end{tabular}

Figure 3. VisitBritain scores required for hotels, valid from August $2011^{2}$

For hospitality owners to participate in VisitEngland's ${ }^{3}$ schemes, they have to meet some basic requirements related to number of rooms, serving of meals and bathroom facilities. Hoteliers have to pay a flat annual rate and then a member of VisitEngland (a trained expert) pays an overnight mystery visit to assess the above criteria and allocate a star rating accompanied by a detailed management report. For the participators who exceed quality of service within their star categories, VisitEngland offers "unique Gold and Silver awards" (see Figure 4). VisitEngland's report states about the awards:

Hotels must demonstrate consistent levels of high quality in the six key areas identified by consumers as very important: A Gold or Silver award gives hotels a significant marketing advantage-they can feature the award logo on their website as well as display their award certificate at their property.
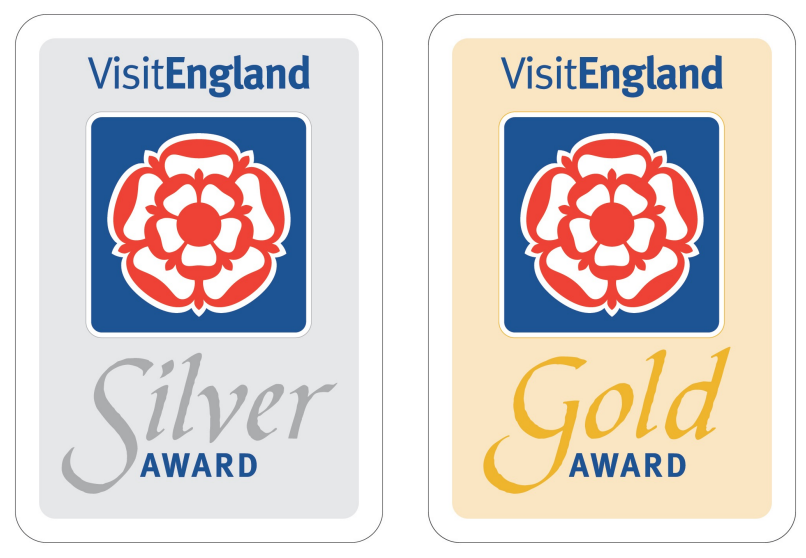

Figure 4. Gold and Silver Awards offered by VisitEngland as signposts of outstanding value.

2 http://www.qualityintourism.com/wp-content/uploads/2014/09/New-Hotel-andGA-Scorecard-2014.pdf.

${ }^{3}$ VisitEngland was merged with VisitBritain but it now acts separately as the tourism board for England. 
Similarly, Scott and Orlikowski (2010) present in detail how the Automobile Association (AA) ranks properties. Besides being a marketing tool for hotel managers such ranking and classification mechanisms broadly inscribe expectations prior to departure and during the stay. These accreditation schemes have been in existence for over 100 years and now condition what most travelers regard as a four- or five-star hotel and set expectations for the hotel experience. For hoteliers, being a member of schemes such as the AA or VisitEngland is a recognized part of organizational sustainability. Outside the UK, there are over 30 hotel classification schemes across Europe, including systems of "stars", "letters", "crowns" and "levels." The Hotelstars Union, a body that aims at establishing a European hotel classification system, ${ }^{4}$ arranged a meeting among the 15 members in January 2014 in Prague toward harmonizing classification standards.

The results of the aforementioned and many more inspection and assessment systems form part of the ratings produced by (national) bodies and in some cases are also included in formal publications used by travelers. All these traditional channels have played a key role in making the value of hotels, restaurants and destinations. The question then arises, what happened when their online manifestations appeared? Could we talk about an evolutionary transition of offline channels onto the web or would their appearance be emblematic of a more radical transformation?

\section{The Algorithmically Powered Valuation Device Called TripAdvisor}

TripAdvisor is the largest travel UGC website where people can anonymously share opinions about hotels, restaurants and attractions; a combination of click-button rating categories and user-generated free text. The click-button data is used to rank hotels and produce a numerical list through a combination of algorithms, the most important of which is the "Popularity Index." The Popularity Index produces a list of properties in a geographical location each of which is allocated a descending numerical position. This creates a novel set of relational dynamics between hotels, algorithms, members, moderators and content managers.

What began as a portal with travel information has evolved into the largest travel website with more than 375 million unique monthly visitors and over 250 million reviews. Its current status is so significant that many believe it is rapidly superseding formal sources of knowledge about travel and making traditional hotel accreditation

\footnotetext{
${ }^{4}$ http://www.hotelstars.eu/index.php?id=about_us.
} 


\section{Valuation Studies}

schemes largely redundant. In 2011, UK Tourism Minister, John Penrose, announced that the official tourist board hotel star-rating system should be abandoned and websites, such as TripAdvisor, would complement any remaining traditional schemes. In an interview on the UK's Radio 4, Penrose said: "We would like to get people to use those websites rather more frequently, but also if the industry wants to carry on running a star-rating system off its own back that is absolutely fine as well." ${ }^{5}$ The Organization of German Hotels and Restaurants, following the Hotellerie Suisse body in Switzerland, went a step further and partnered with a social-media monitoring platform to analyze reviews and ratings produced by users and algorithms. ${ }^{6}$ The scores are then combined with professional reviews which in turn produce "a new star rating" for each property.

Much electronic ink has been spilled by bloggers and travel writers on guessing how TripAdvisor rankings work and especially on spotting grey areas of the mysterious algorithm. The TripAdvisor team provides support, so that there is a strict and thorough screening process of every single review in place to ensure quality. TripAdvisor's Director of Communications Europe said during our interview in London:

Fortunately on our site we have very strict controls, we invest a lot of money and time, we have people reading each review to make sure it's not defamatory. So, strict controls are in place and that's the kind of day-to-day worries that show that what you are providing the consumer is good quality without compromising on the objectivity of the content.

Similarly, Steven Kaufer, Co-founder and CEO of TripAdvisor, in our interview in Boston gave his answer to how the algorithm works:

We want our results to be as authentic as we can possibly make them. In the end of the day when you have 500 reviews its almost hard for an algorithm to go wrong but for instance a review written 4 years ago in our system doesn't carry the weight that a review written yesterday does. You know, if I told you exactly the weighting it wouldn't be meaningful to you, it's not particularly meaningful to me.

Irrespective of the extent to which the algorithms make visible stories tourists can resonate with, or in other words having in mind Knorr Cetina's "epistemics of information" irrespective of the validity of stories produced on line, tourists have been engaging with the TripAdvisor device as if it were a pivotal piece of their travel experience. Many confessed they do not go on a trip or visit any place without checking TripAdvisor first. They even go on to add that UGC

5 http://www.breakingtravelnews.com/news/article/government-to-abandon-hotelstar-rating-system/

6 http://www.tnooz.com/article/germany-overhauls-hotel-star-rating-systemcombines-pro-and-user-reviews/ 
has served as a life jacket: "Trip Advisor saved me from staying at a hotel in a bad location in Lisbon", says a participant in one of our interactions. Another user notes, "I don't have to go blindly on a trip. I can know just about everything I need to know or choose to know before I book."

From the hoteliers' side, it is about negotiating reality. A general manager from a hotel in Mexico aptly sums up the relationship between reality and engaging with TripAdvisor: "One must realize that irrespective of what we may think is the 'reality' ... the reviewer has submitted their 'reality', and it is our goal to somehow close the gap if any between our intended reality and the guests perceived reality." The perceived realities as shared by others is what tourists of all ages care about. Discussions with participants of the study made clear that contemporary tourists perform meta-evaluations, in that they not only care about the places that are ranked and rated but they also have certain expectations from the valuing device of TripAdvisor as opposed to its predecessors. Below, a participant comments on the nature of content that can be found on TripAdvisor but not in "official" travel guides:

That restaurant is great is not enough info. Do they give senior discounts? Can we wear jeans? Do they have high chairs? Would I look weird if I was eating alone? Is it a romantic place? Every sub-group has their own list of requirements. Very dynamic!

A common pattern that is found in most conversations with travelers:

[And] this is just as important as ratings, the reviews give you details about the accommodations that you just don't get in short, summary reviews in AAA books or travel books. You might find out that there is a great bagel shop just 1/4 mile from the motel. Or that the hotel has tennis courts, and will lend you rackets. Or that during ski season, a particular resort hotel is a singles heaven, but that it's great for families in the summer.

Similarly another user commented with humor about what in his opinion travel guides fail to achieve:

Because the travel books give one short perspective watered down to a short sentence that is often filled with ridiculous and useless comments like my personal favorite "the hotel lacked soul" now what the $\mathrm{h} * *$ is THAT supposed to mean? Turned out it meant the staff were rude and tried their best to rip you off, the rooms were dirty and there was no hot water. Hmm-why couldn't they have just said that?

Users contribute reviews about places in an effort to negotiate their multiple accounts and to communicate either the dark sides that cannot be found elsewhere or the bright ones that no one else cares to present: 


\section{Valuation Studies}

You read a description of a hotel on its site or other sites that are commercially linked to it and it sounds like the Garden of Eden. You check on user-generated websites and the place is a dump. Commercial sites cannot be trusted to be unbiased and objective. People always trust word of mouth endorsements a great deal. If someone tells me the new restaurant down the street is great ... I will probably go and try it.

Interestingly, it is not only the disparity between official and unofficial or objective and subjective content that differentiates TripAdvisor, but it is rather more complex than that. TripAdvisor is a valuing device in its own right. It appears infinitely malleable in the hands of users/ tourists and somehow invites them to be creative in how they afford new possibilities of engagement. One of those moments of creativity was what the Community and Forum specialists described during the focus group in London, with a user seeking for updates on the construction of a hotel.

It was on the English forum I think, somebody who was going to stay in a hotel but it was a new hotel and they hadn't finished building it yet and they were on the forum asking has anyone been there? Do you know is it finished? I'm going in 2 weeks time and I'm terrified I'm gonna turn up and it's a building site. And on the English site there was somebody who was living there who was going and taking photographs every day and putting up photographs of all the stages of the building, so that people would know whether their rooms were built yet. I just thought it was fabulous (TA focus group, Community and Forum specialists).

Users on TripAdvisor share their own realities about places and in so doing they make places. In some cases travelers have "discovered" places because of reviews on TripAdvisor or they have changed their decisions about visiting a place:

Gotten lots of good tips on nice hotels through TripAdvisor. Found hotels I would never have found in other ways ... I think that Internet has changed the choices we make and the cities we visit, said a user.

It is not only the choices and perceptions that change, but also the ways in which users engage with the mechanisms in place. Mellet et al. (2014) discuss how the emergence of a new consumer voice-online restaurant review sites-has epitomized an era of "empowerment" and "democratization." Users in our study have referred to empowerment in the form of intervention. A TripAdvisor user narrates why she contributes content about her hometown:

My own town gets a very bad press. There are serious misconceptions that it is a dangerous city and that there are no viable attractions. I contribute to correct such negative and damaging stereotypes and to encourage people to visit my wonderful city. 
The contributor is hoping to change the way that a place-her hometown-is perceived. This is what value means to her.

When participants talk about practicing TripAdvisor, they seem to ignore the dichotomy between physical and on line. They are aware of how editorial decisions in guide books and official marketing campaigns promote their specific agendas, but the algorithmic configurations become somehow invisible and the stories that accompany scores simply mingle with physical places and make such dichotomies unproductive and irrelevant. Similarly, sharing experiences with fellow travelers and consuming others' stories-reviews-has become an inseparable part of the travel experience. "My friends joke that I gain such pleasure from planning vacations that the actual trip is anticlimactic", said a user, while another summarized how the before, during and after of the travel experience mingle and become inseparable:

Travel Experience means everything from planning to memories long after the actual event. At the moment, I'm preparing for a Fear of Flying Course. I'm doing hypnosis, I'm learning to relax. This, for me, is all part of a travel experience. I am traveling across the country to do this flying course and will be staying in a hotel for two nights. And even planning my holidays this year, looking at maps, researching trips, these are all part of the experience.

A traveler and destination expert on TripAdvisor shared in one of our online interactions how she started traveling before the feet performed the journey through the pages of National Geographic and pictures of the Eiffel Tower:

Travel means seeing, experiencing, and learning other parts of the world, as well as a break from ordinary daily routine life. I first got interested in travel when I was 13 and still going to school. My teacher that year drew me a picture of the Eiffel Tower, and told me about the time that he went to Paris and had lunch right there on the Eiffel Tower. I also used to go to both the local public and school libraries and took books out about different countries, as well as National Geographic magazines.

Another traveler shared his version of traveling through reviewing and remembering:

[A]lso I travel vicariously through my contributions ... someone asks ... where can I have a nice lunch in Buenos Aires ... I start thinking ... hmmm ... the Café Tortoni or Café Biela ... and I am mentally back sitting outside at a table ... drinking a café con leche and eating a Sandwich de Miga ... The questions and answers help me relive good and at times bad experiences.

Users on TripAdvisor consume places in multiple ways. They read and write stories about distant and familiar places-destinations, hotels, attractions-they interact with travelers and hoteliers and negotiate 


\section{Valuation Studies}

truth, they make the invisible visible, they trust, they believe, they value, they doubt: they make places. As we move from the embassy and the vetturini to the crowd that submits reviews and scores about places, we observe how the practices of valuation have changed along with what is considered to be valued. These transformations have not occurred in a linear way, nor has any device replaced the other in any straightforward way. Somehow they all coexist while different weights are being attributed to them, which in turn influence how value is perceived. For instance, TripAdvisor stories are similar to the travel diaries of the Grand Tour and possibly the same stories that tourists write on guest comment cards. Nevertheless, they all matter differently due to the complex configurations of the broader mechanisms of which they are part. Irrespective of the specificities of each valuing mechanism, what they all have in common is the self-reinforcing behaviors they put in motion; feedback mechanisms and assessment schemes are two sides of the same coin (see Table 1 for a summary).

\begin{tabular}{|c|c|c|}
\hline Age & Valuing devices & Mechanisms \\
\hline $\begin{array}{l}\text { Grand } \\
\text { Tour }\end{array}$ & $\begin{array}{l}\text { Diaries and travelogues } \\
\text { Vetturini and bear leaders }\end{array}$ & $\begin{array}{l}\text { Autobiographical travel } \\
\text { accounts and first travel guides } \\
\text { introduce early travel practices }\end{array}$ \\
\hline $\begin{array}{l}1500- \\
1600 s\end{array}$ & $\begin{array}{l}\text { Letters, travelogues, personal } \\
\text { accounts } \\
\text { Bankers and ambassadors }\end{array}$ & $\begin{array}{l}\text { Formal and informal sources } \\
\text { shape reputations about places } \\
\text { and minimize uncer- tainty }\end{array}$ \\
\hline 1893 & Published travel guides & $\begin{array}{l}\text { Information is presented as } \\
\text { factual }\end{array}$ \\
\hline $1980 \mathrm{~s}$ & SERVQUAL & $\begin{array}{l}\text { Institutionalization of best } \\
\text { practices }\end{array}$ \\
\hline $1900-$ & $\begin{array}{l}\text { Emergence of Michelin Guides } \\
\text { and other national classification } \\
\text { systems and accreditation } \\
\text { schemes }\end{array}$ & $\begin{array}{l}\text { Formal authorities perform } \\
\text { assessments and define } \\
\text { standards }\end{array}$ \\
\hline $1990-$ & Guest comment cards & $\begin{array}{l}\text { Feedback mechanisms in } \\
\text { evaluating service }\end{array}$ \\
\hline $2000-$ & $\begin{array}{l}\text { UGC and the crowd Ratings, } \\
\text { rankings and algorithms }\end{array}$ & $\begin{array}{l}\text { Bottom-up creation of lists, yet } \\
\text { algorithmically configured }\end{array}$ \\
\hline $2004-$ & Hybrid systems & $\begin{array}{l}\text { Experts, travelers and } \\
\text { algorithms co-produce } \\
\text { contemporary standards, } \\
\text { evaluate and create } \\
\text { expectations }\end{array}$ \\
\hline
\end{tabular}

Table 1. Valuing devices over the years. 
But the question remains: Could we talk about an evolutionary transition of offline channels onto the web or would TripAdvisor's (and other UGC websites') emergence be emblematic of a more radical transformation? In the next section we discuss how UGC might depart from previous valuing devices and effect new kinds of place-making.

\section{Place-making: Are Places Performed Differently as Valuing Devices Evolve?}

Before we enter into our discussion of place-making and its relationship to valuation, we first need to grasp the multiplicity that characterizes performing a place through traveling. In the following published review, a user on TripAdvisor shares his/her experience:

From the fast response of the first email contact, Sebastien and staff demonstrated how they have earned the top slot in the Angkor area. From lemongrass tea upon arrival, fun and friendly tuk-tuk transportation, stylish accommodations, relaxing garden and pool, Khmer bedtime stories, to secret gifts upon checkout! We WILL be back to this charming hotel. They exceeded our expectations by paying attention to the small details that are appreciated rather than getting distracted by the big ones that don't really matter. Thanks for a perfect weekend! (User review posted on TripAdvisor)

The above story involves multiple spatial arrangements. From a Cartesian perspective that treats spaces as geographic containers we would say that the experience started within the premises of the hotel and then transferred to the internet through the review posted as a representation. However, having adopted a relational approach, we understand the hotel as one place that is enacted in multiple ways. Hence, we claim that a separation between off line and on line, between physical territories and their online manifestations, would be a misleading bifurcation. The two interrelated enactments -which are actually one and not two-are-or is-a co-constitutive whole that becomes a place for negotiating what the travel experience is and what the place becomes in infinite ways. This infinite variety of becoming a place that has been informed since the emergence of UGC has in turn propelled us to emphasize the enactment of placeness as integral to contemporary valuation practices.

The cornerstone of the argument is that places are enacted while practicing them in infinite ways and combinations. When travelers (from Grand Tourists to modern travelers) share their experience of traveling, with or without ratings, they not only refer back to the place as it was as if it stopped becoming when they physically left it, but they keep making the place. By embracing this multiplicity we achieve a revised understanding of place as at once whole and multiple in practice and we give further meaning to the tourist gaze. John Urry (1990) introduces the notion of the tourist gaze to theoretically frame 


\section{Valuation Studies}

the touristic experiences travelers gain while encountering sights, nature, buildings. Examples of the object of the tourist gaze include "a landscape (Lake District), a townscape (Chester), an ethnic group (Maoris in Rotorua, New Zealand), a lifestyle (the wild west), historical artifacts (Canterbury Cathedral or Wigan Pier), bases of recreation (golf courses at St Andrews), or simply sun, sand and sea (Majorca)" (Urry 2002, 51). ${ }^{7}$ The tourist gaze reminds us of what Haraway (1991, 191) notes about eyes being "active perceptual systems, building in translation and in specific ways of seeing, that is ways of life", or if we paraphrase her, that is ways of traveling.

In other words, travelers explore places, gaze at them, inhabit them temporarily, interact with their constitutive elements: people, buildings, nature, culture, etc.-check-in on line and off line, rate them and as they practice places they recreate them in interesting ways. In this sense places on TripAdvisor and UGC websites are "open places" and undifferentiated from their physical manifestations. As incoming information is shared on line, the places are reconfigured through algorithms, and valuation is enacted in ways that have the potential to further transform another interrelated enactment of places, which is our visit to them. TripAdvisor as another enactment of the hotel as an open place has somehow absorbed the duality between physical and online. The tourist gaze has been practiced on line with different outcomes for places. Dodge and Kitchin (2004) in their analysis of electronic and physical interrelationships between code and space emphasize the becoming nature:

[c]ode/space is constantly in a state of becoming, produced through individual performance and social interactions that are mediated, consciously or unconsciously, in relation to the mutual constitution of code/space. [T] he nature and production of code/space are never fixed, but shift with place, time, and context.

As the geographer Doreen Massey (2005, 140-1) argues we are witnessing "the way that very diverse elements that cross categories such as the natural or social come together to foster a particular 'here and now'. This is what makes places specific-this gathering of diverse entities into relation", and not the artificial dichotomies like offlineonline. Practices do not happen in places but along with them, they are co-constitutive. For example a hotel as a "thing" in a territory does not mean much, until travelers visit it, take pictures of it, experience its service, interact with the staff and most recently write about it on the internet. What place means is perpetually negotiated, as with every phenomenon in a state of becoming. Simonsen notes that "places are meeting points, moments or conjunctures, where social practices and

\footnotetext{
7 In the 2nd ed. Urry discusses how mobility and new technologies have advanced the practice of gazing.
} 
trajectories, spatial narratives and moving or fixed materialities meet up and form configurations that are continuously under transformation and negotiation" $(2008,22)$. With the emergence of UGC the places where these negotiations occur have been enacted differently. What place becomes at any one time is produced through its constitutive relations. Participants in the study confirmed their experience of traveling as such.

Travelers shared about their imaginary travels through pictures and books. Having lunch on the Eiffel Tower is a strong evocation; even the act of talking about it creates the place both for the narrator and the listener. While the place is being created, the desire to visit the romantic scene and become part of it becomes more intensive. We suggest that in some extraordinary way, traveling is enacted when "listening" to a story. The travel to Eiffel Tower and many more happened while looking at pictures and the pages of National Geographic. After some time, the reader herself became part of the travel experience for other travelers when she wrote hundreds of reviews and forum posts on TripAdvisor. This discussion reminds us of Nicholas Negroponte's (1995, 165) words:

Digital living will include less and less dependence upon being in a specific place at a specific time, and the transmission of place itself will start to become possible. If I could really look out the electronic window of my living room in Boston and see the Alps, hear the cowbells, and smell the (digital) manure in summer, in a way I am very much in Switzerland.

Imagination is thus encapsulated within (and overflows) practice while traveling is enacted in innumerable ways. Travelers can make the journey before or after the feet perform it. Travel is performed and enacted via storytelling, through narrating and listening, viewing and reviewing. The use of "listening" in the context of UGC postings functions as a reifying metaphor. Ingold explains that "to read is not just to listen but to remember. If writing speaks it does so with the voices of the past, which the reader hears as though he were present in their midst" $(2007,15)$. The iconic travel through stories is a performance of (re-)creation too. Solnit $(2001,72)$ notes that "to write is to carve a new path through the terrain of the imagination, or to point out new features on a familiar route. To read is to travel through that terrain with the author as guide." What TripAdvisor and other valuing devices achieve is the production of combinations of people and relationships that would not otherwise emerge.

Keeping the experience alive, even if only in the imagination, has been a crucial part of the travel practice. UGC and TripAdvisor do not come as a novelty out of nowhere, but instead are products of a consistent ongoing process. Even the idea of place-making, as presented here, could be traced through history to some roots in the 


\section{Valuation Studies}

"Raree showmen" (see Figures 5 and 6), who wandered around offering people imaginative travels (peep shows) to places that they would never visit physically. Della Dora $(2009,336)$ gives a nostalgic account of the boxes Raree showmen carried:

Boxes of all sorts: portable wooden stereo-scopic boxes, which allowed children to travel to marvellous cities they could hold in their hands; alabaster egg-shaped boxes containing sublime sceneries; dioramic boxes, carrying landscapes that changed with the variation of light ... [c]ontaining illusionist panoramic paintings wrapping the visitor, offering him a real-like experience of the actual place they represented. What all these boxes shared was their hidden and yet liberating spatiality; their physical containment and their ability to take the viewer further, visually and imaginatively.

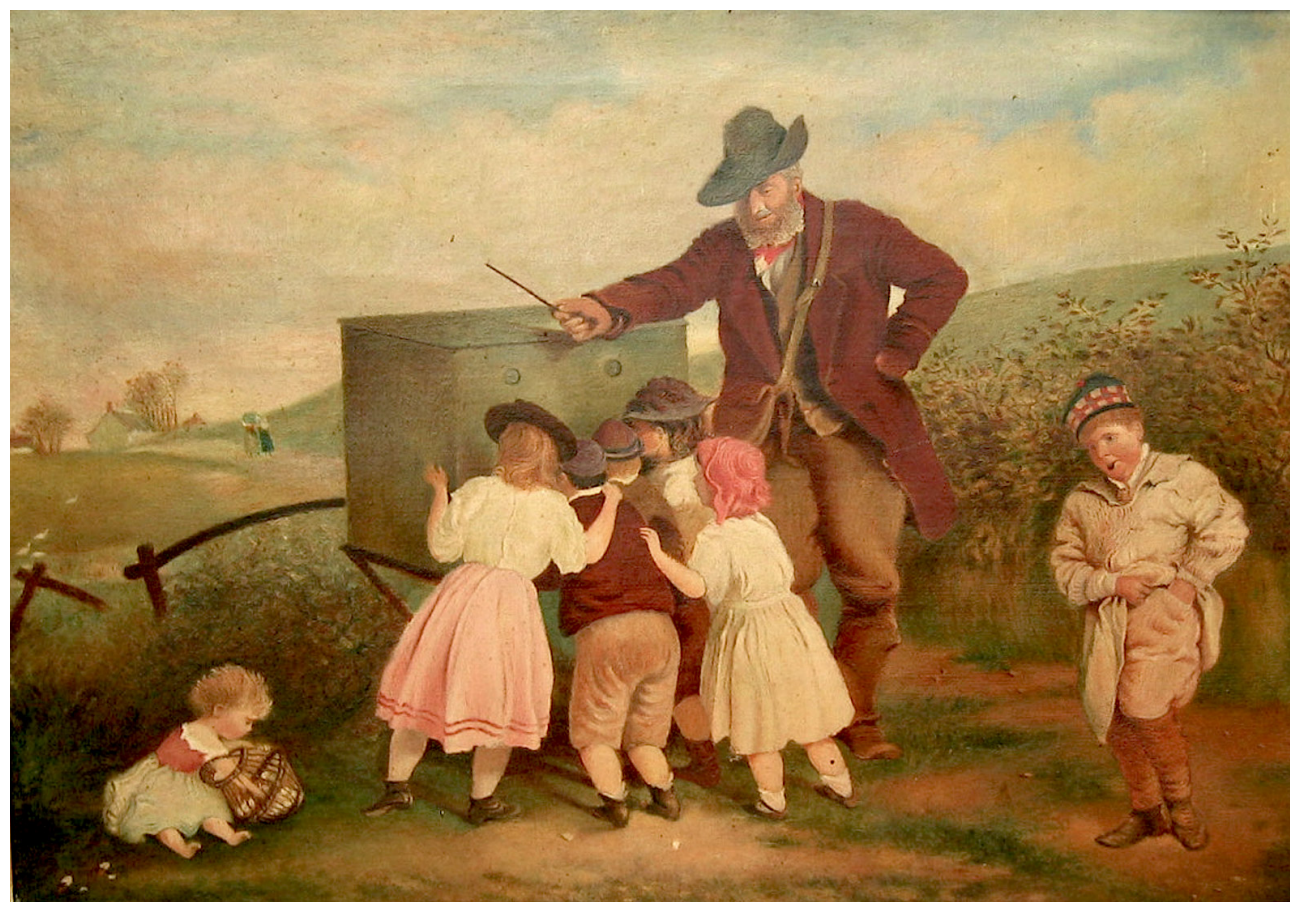

Figure 5. The Peep Show, oil on canvas, anon., Great Britain, c.1840. Courtesy of the Richard Balzer Collection. ${ }^{8}$

The author claims that Raree showmen have not disappeared but rather multiplied. They have taken different forms of creating placeness. Souvenirs for instance "crystallize time and space", as people try to keep moments of remembrance untouched. Travelers carry the place they visited and the memories attached within a small box or package. The idea of preserving place and time by carrying it home is in accordance with the becoming of place. As we carry places in different ways we reshape their value, when we think about them, talk, write and create images. Thus UGC is another form of

8 More information and pictures about raree showmen, peep shows and other 'cabinets of curiosities' can be found at http://www.dickbalzer.com/Peepshows. 202.0.html. 
crystallizing place and time and carrying it home. What is different from the souvenir is that this sense of "placeness" is imaginatively shared and relived within a community of travelers/users. No matter whether we have chosen to carry home the practices in the format of memories or a souvenir, when we write a review on line we perform value anew and this performance in combination with a series of algorithmic configurations has further consequences for hospitality professionals.

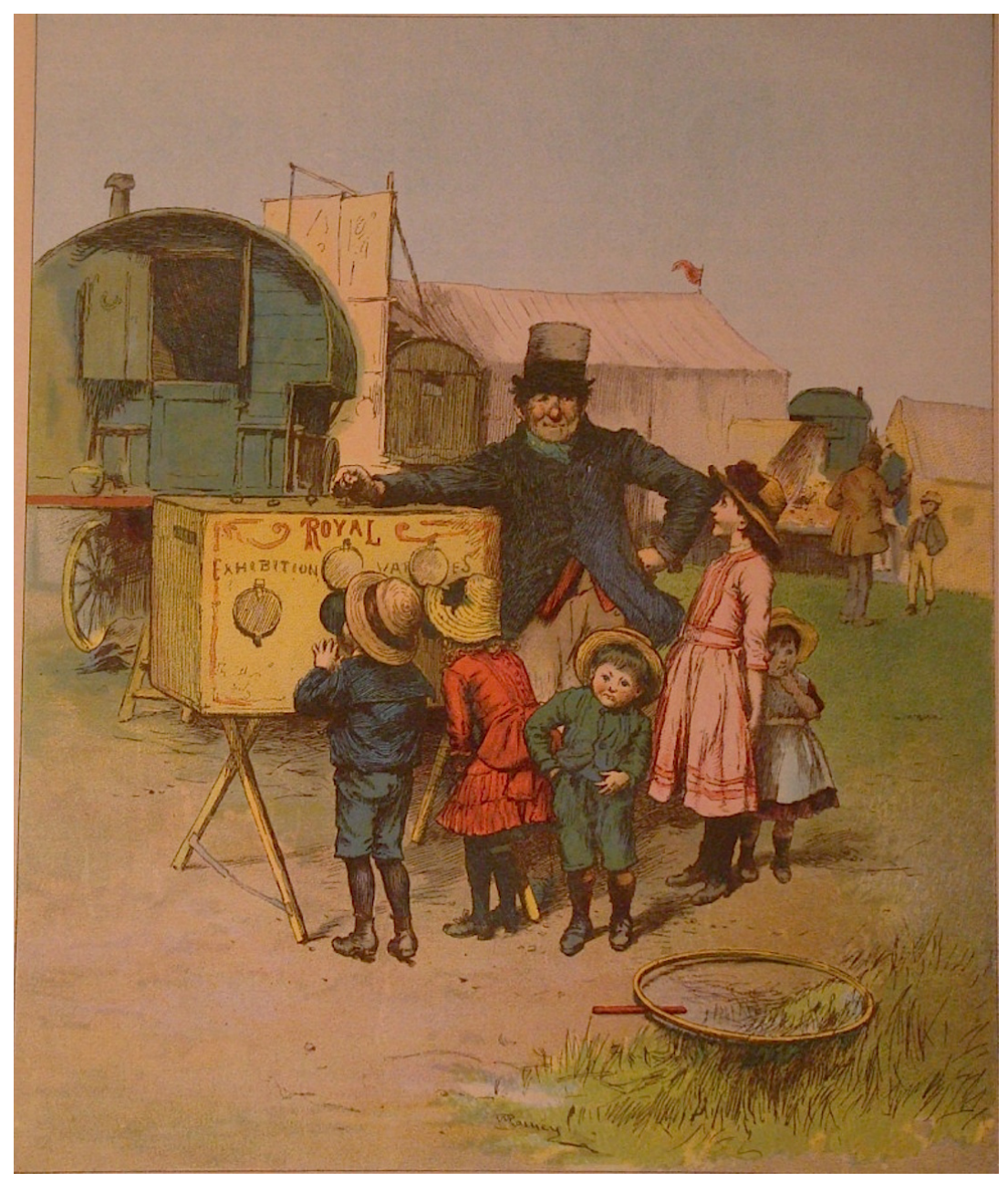

Figure 6. Royal Exhibition, W. Rainey, Great Britain, c.1900. Courtesy of the Richard Balzer Collection.

UGC, as a powerful illustration of the "epistemics of information" makes places and values irrespective of whether stories have been experienced or not; irrespective of whether travelers have actually visited the place or they are submitting fake accounts. Scott and Orlikowski (2012) in studying the relations of accountability point to the multiple evaluation principles in play embedded in traveler reviews 


\section{Valuation Studies}

on TripAdvisor and emphasize that what constitutes "value" to one traveler may be different from another. In this study and earlier studies looking at the phenomenon of TripAdvisor (see Baka and Scott 2011a, $2011 \mathrm{~b}$ ) the material and discursive consequences that are entangled with the algorithmic power and the associated crowd do matter in the everyday life of professionals in the travel sector and in the long-term sustainability. In many cases hotel and restaurant managers figuring in TripAdvisor's "Worst Lists" and in the "Horror Stories" Newsletters have been forced to prove that a review is inaccurate and even defend their business in court.

The imaginative practice of traveling has fueled a series of recognized performative outcomes for modern tourists too. Oftentimes tourists visit places to experience what has been communicated through the media. However, when performed experience does not live up to expectations there are consequences. In extreme cases, such as "Paris Syndrome", tourists collapse and may suffer from a psychosomatic mental illness. This alarming turn of events became so notable among Asian tourists that "Paris Syndrome" now appears as a formal entry in medical journals. It is regarded as a severe case of what is commonly referred to as culture shock; during their visit to Paris individuals expect to experience the cosmos of "Amelie", "Louvre" or the "Luis Vuitton" lifestyle, but instead find themselves assaulted by dissonant unromantic moments and rude conversations. This disappointment then manifests through symptoms such as dizziness, tachycardia, sweating, etc. Similar psychoses have been reported in other highly evoked places, for example "Jerusalem Syndrome" in which travelers become psychotic and suffer from intense religiously related mental problems after arriving in the Holy City; or "Florence Syndrome" (also known as the Stendhal syndrome), whereby tourists exposed to Florentine art cannot absorb their experiences and develop the symptoms described earlier. In this respect UGC has intensified this enactment of traveling which is evoked intensively before the feet perform the journey, and instead of providing yet another promotion platform, it has remade the place where traveling occurs. As one user and destination expert on TripAdvisor said: "My life would be rather less complicated without TripAdvisor but it would also be less fulfilling."

The development of social media has encouraged us to talk-even more than with other media-about the generative mechanism of making places beyond seeing or flying, through different enactments such as imaging, imagining, reading, writing. Tourists of the modern age contextualize the landscape using their own terms and performatively contribute to its (re-)creation. A traveler wrote on an online community how the act of reading on TripAdvisor transformed her perception of New York, even though she had visited the place 14 times: 
I did a walking food tour of Greenwich village and Soho the last time I was in New York. I followed the advice of a local expert (on TripAdvisor) and I am sure glad I did because it was one of the more fun things I did in New York ... and I have been to the city 14 times!

A simple piece of advice from a local transformed her view of a very well-known city. She therefore rediscovered New York. The power of engaging with UGC is that the knowledge that we have about a place is creatively destroyed and in a generative, performative way this recreates the place itself, as we take a decision to visit it or not, to be thrown together in it or not.

The different enactments that we are witnessing with the emergence of the internet and UGC have not brought about a whole "new" pristine era of communication and interaction, but they make differences in an ongoing world. Meyrowitz (1985) in his classic analysis refers to how television has been approached with a focus on the effects of violent or sexist content, whereas what has been largely ignored are the different ways of communicating cultural content that may lead to different social conceptions of childhood, adulthood, masculinity, etc. And he continues that we see half a picture when we merely look at what media bring into the home and do not recognize the possibility that new media transform the home and other social spheres. In a parallel way, we claim that with the emergence of travel UGC, relationships have been intensified with consequences for what it means to be a host, a guest or a great hotel at any one time and place. Earlier valuing devices have evoked place-making in various ways, yet the rise of TripAdvisor has converted the travel experience into a constant negotiation process whereby both the value of places and the value of the valuing device are contested.

The meta-evaluation process of judging the device is very much associated with the algorithmic configurations. Places are made and remade every time travelers talk, write and share but also through the associated algorithms in place that allow stories to make an impact and rankings to be created. Travelogues, guide books, travel diaries, brochures, the internet and other forms of media have also had performative implications but the devices of UGC websites invite us to talk about algorithmically powered performativity as a process in its own right. Earlier we reviewed performativity as sociological, economic and linguistic and how scholars have developed our knowledge of performativity beyond the linguistic context, as introduced by Austin. However, algorithmically powered performativity adds a further layer of complication and encourages us to question about where, when and how valuation manifests as it is (per)formatively enacted. Spatiality is revisited through a unified understanding of off line/on line, and "lateral forms of accountability" (Stark 2009, 19) are created as UGC is placed 


\section{Valuation Studies}

alongside formal accreditation schemes and information from hoteliers. In the end what and who is held to be valued remains a highly contested issue. In other words, valuation happens continuously through a formative process.

\section{Concluding Remarks}

In this paper, we defined placeness by taking UGC seriously as illustrative of contemporary valuing devices and suggested that places should be treated as open and unfolding rather than as fixed territories. The paper has illustrated how places continue to develop as we perform traveling in various ways. What the place momentarily becomes is constitutive of the arrangements of relationships and interactions among diverse "elements" that cross categories in time. In this light, the value of the hotel or destination emerges as people, moods and algorithmic configurations are thrown together, and as such it is very much contingent upon space and time. The becoming of places supports the idea that places are constantly constructed and remade. Nowadays more than ever temporality reshapes our perception of places and thus their offline and online manifestations are interrelated enactments of the same unified "place."

Although valuing devices in travel have always been performative, traveling has been transformed since the emergence of UGC. Most everyday practices have been influenced by the presence of the online sphere, yet traveling is a category of particular interest as the "before", "during" and "after" are intertwined and transcend the physical and online definitions of space and code. This inseparability of the before, during and after is further intensified because of the affordances of the algorithmic configurations that have the power to make things (in)visible and hence has inspired new ways of place-making. Travelers/users experience and enact places by looking at them, by seeking for information through various channels, by posting their accounts of how they have performed traveling and by co-creating experiences to the extent that the assemblages of algorithmic structure and agency allow it.

The paper has distilled the generativity of places conceived as practices and doings. In that sense, places are practices yet also in the making; they are implicated once performed and this is an ongoing process. Not only do we experience places in everyday encounters with people and "things", but places are negotiated and performed as processes of those relationships. As people are "thrown together" in Rome or in a forum talking about Rome the borderline between physical and on line becomes meaningless and Rome emanates as a process through those interactions. Places are remade once we step on them or talk about stepping on them. This is the performativity of place-making that is enacted through imagination or is realized in the form of a decision when UGC postings along with the associated 
algorithmic configurations and ordering mechanisms convince people to visit a place. Like other ordering devices, algorithmically powered and powerful generative mechanisms are highly entangled with valuation practices. Although all (e)valuation mechanisms over time are illustrative of the multiplicity of performativity, in the case of TripAdvisor and UGC value is performatively made and remade through algorithmic configurations and enacted through reading, interpreting, writing, imagining-or in other words through placemaking.

\section{References}

Appadurai, Arjun. 1986. "Introduction: Commodities and the Politics of Value." In The Social life of Things: Commodities in Cultural Perspective, edited by Arjun Appadurai, 3-63. Cambridge: Cambridge University Press.

Attride-Stirling, Jennifer. 2001. "Thematic Networks: An Analytic Tool for Qualitative Research.” Qualitative Research 1 (3): 385-405.

Augé, Marc. 1995. Non-places: Introduction to an Anthropology of Supermodernity. London-New York: Verso,.

Austin, John Langshaw. 1975. How to Do Things with Words. W. James lectures delivered at Harvard, 1955. Cambridge, MA: Harvard University Press.

Baka, Vasiliki, and Susan Scott. 2011a. "Exploring the 'Becoming' of Social Media: The Entanglement of TripAdvisor Algorithms in the Transformative Processes at Work in the Travel Sector", Third International Symposium on Process Organization Studies: How Matter Matters: Objects, Artifacts and Materiality in Organization Studies, Corfu, June.

- 2011b. "The Circle of (il)Legitimacy and a Revised Agenda for Reputation Management in the Era of Social Media”, EGOS (European Group for Organizational Studies) Conference, Gothenburg, July.

Brodsky-Porges, Edward. 1981. "The Grand Tour Travel as an Educational Device 1600-1800.” Annals of Tourism Research 8 (2): 171-186.

Callon, Michel, and Fabian Muniesa. 2005. "Peripheral Vision: Economic Markets as Calculative Collective Devices." Organization Studies 26 (8): 1229-1250.

Cartier, Carolyn. L., and Alan. A. Lew. 2005. Seductions of Place: Geographical Perspectives on Globalization and Touristed Landscapes. USA-Canada: Routledge,

Dann, Graham. 1999. "Writing out the Tourist in Space and Time." Annals of Tourism Research 26 (1): 159-187.

Della Dora, Veronica. 2009. "Travelling Landscape-Objects." Progress in Human Geography 33 (3): 334-354. 


\section{Valuation Studies}

Dodge, Martin, and Robert Kitchin. 2004. "Code, Space and Everyday Life." Centre for Advanced Spatial Analysis (UCL), CASA Working Papers 81, London: Centre for Advanced Spatial Analysis.

- 2005. "Code and the Transduction of Space." Annals of the Association of American Geographers 95 (1): 162-180.

Espeland, Wendy Nelson, and Michael Sauder. 2007. "Rankings and Reactivity: How Public Measures Recreate Social Worlds." American Journal of Sociology 113 (1): 1-40.

Evans-Pritchard, Edward Evan. 1940. The Nuer: The Political System and Mode of Livelihood of a Nilotic People. Oxford: Oxford University Press.

Galani-Moutafi, Vasiliki. 2000. "The Self and the Other: Traveler, Ethnographer, Tourist.” Annals of Tourism Research 27 (1): 203-224.

Gillespie, Tarleton. 2014. "The Relevance of Algorithms." In Media Technologies: Essays on Communication, Materiality, and Society, edited by T. Gillespie, P. J. Boczkowski, and K. A. Foot, 167-194. Cambridge, MA: MIT Press.

Graeber, David. 2001. Toward An Anthropological Theory of Value: The False Coin of Our Own Dreams. New York: Palgrave Macmillan,

Hannam, Kevin, Mimi Sheller, and John Urry. 2006. "Editorial: Mobilities, Immobilities and Moorings." Mobilities 1 (1): 1-22.

Haraway, Donna. 1991. Simians, Cyborgs, and Women: The Reinvention of Nature. London: Free Association Books.

Helgesson Claes-Fredrik, and Fabian Muniesa. 2013. "For What It's Worth: An Introduction to Valuation Studies." Valuation Studies 1 (1): 1-10.

Herman, Andrew, Rosemary.J. Coombe, and Lewis Kaye. 2006. "Your Second Life?" Cultural Studies 20 (2-3): 184-210.

Ingold, Tim. 2007. Lines: A Brief History. London: Taylor \& Francis.

Karpik, Lucien. 2010. Valuing the Unique: The Economics of Singularities. Princeton, NJ: Princeton University Press.

Kirby, Vicky. 2006. Judith Butler: Live Theory. London: Bloomsbury.

Kjellberg Hans, and Alexandre Mallard. 2013. "Valuation Studies? Our Collective Two Cents." Valuation Studies 1 (1): 11-30.

Kluckhohn, Clyde. 1949. "The Philosophy of the Navaho Indian." In Ideological Differences and World Order, edited by F. S. D. Northrop, 356-384. New Haven, CT: Yale University Press.

Knorr Cetina, Karin. 2010. "The Epistemics of Information: A Consumption Model.” Journal of Consumer Culture 10 (2): 171-201.

Kozinets, Robert V. 2002. "The Field behind the Screen: Using Netnography for Marketing Research in Online Communities.” Journal of Marketing Research 39 (1): 61-72.

Lamont, Michèle. 2012. "Toward a Comparative Sociology of Valuation and Evaluation.” Annual Review of Sociology 38 (1): 201-221.

Lyotard, Jean-François. 1984. The Postmodern Condition: A Report on Knowledge. Theory and History of Literature. Minneapolis, MN: University of Minnesota Press. 
MacKenzie, Donald. A. 2006. An Engine, Not a Camera: How Financial Models Shape Markets. Cambridge, MA: MIT Press.

Massey, Doreen B. 2005. For Space. Thousand Oaks, CA: Sage.

Mellet Kevin, Thomas Beauvisage, Jean-Samuel Beuscart, and Marie Trespeuch. 2014. "A 'Democratization' of Markets? Online Consumer Reviews in the Restaurant Industry." Valuation Studies 2 (1): 5-41.

Meyrowitz, Joshua. 1985. No Sense of Place: The Impact of Electronic Media on Social Behavior. Oxford: Oxford University Press.

Negroponte, Nicholas. 1995. Being Digital. Coronet Books. USA-Canada: Hodder and Stoughton.

Perkins, Harvey, and David C. Thorns. 2001. "Gazing or Performing? Reflections on Urry's Tourist Gaze in the Context of Contemporary Experience in the Antipodes.” International Sociology 16 (2): 185-204.

Petticrew, Mark, and Helen Roberts. 2006. Systematic Reviews in the Social Sciences: A Practical Guide. Malden, MA: Blackwell Publishing.

Power, Michael, Tobias Scheytt, Kim Soin, and Kerstin Sahlin. 2009. "Reputational Risk as a Logic of Organizing in Late Modernity." Organization Studies 30 (2-3): 301-324.

Rao, Hayagreeva. 1994. "The Social Construction of Reputation: Certification Contests, Legitimation and the Survival of Organizations in the American Automobile Industry.” Strategic Management Journal 15: $29-44$.

Renganathan, R. 2011. "Service Quality in Hospitality Services: Gap Model and Factor Analysis." European Journal of Social Sciences 26 (2): 159175.

Sahlins, Marshall. 1976. Culture and Practical Reason. Chicago, IL: University of Chicago Press.

Scott, Susan, and Wanda Orlikowski. 2010. "Reconfiguring Relations of Accountability: The Consequences of Social Media for the Travel Sector", Annual Meeting of the Academy of Management, Montreal, QC, 6-10 August 2010.

- 2012. "Reconfiguring Relations of Accountability: Materialization of Social Media in the Travel Sector." Accounting, Organizations and Society 37 (1): 26-40.

Sharp, Samuel. 1767 [2010]. Letters from Italy, Describing the Customs and Manners of That Country, in... 1765 and 1766. To Which Is Annexed, An Admonition to Gentlemen Who Pass the Alps, in Their Tour through Italy. London (2010 ed. Whitefish, MT: Kessinger).

Sheller, Mimi, and John Urry. 2006. "The New Mobilities Paradigm." Environment and Planning A 38 (2): 207-26.

Simonsen, Kirsten. 2008. "Place as Encounters: Practice, Conjunction and Co-existence." In Mobility and Place: Enacting Northern European Peripheries, edited by J. O. Barenholdt and B. Granås, 13-26. Burlington VT and London: Ashgate.

Solnit, Rebecca. 2001. Wanderlust: A History of Walking. New York, NY: Penguin Group USA. 


\section{Valuation Studies}

Spicer, Andre, Mats Alvesson, and Dan Kärreman. 2009. "Critical Performativity: The Unfinished Business of Critical Management Studies." Human Relations 62 (4): 537-560.

Stark, David. 2009. The Sense of Dissonance: Accounts of Worth in Economic Life. Princeton, NJ: Princeton University Press.

- 2011. "What's Valuable?" In The Worth of Goods: Valuation and Pricing in the Economy, edited by J. Beckert and P. Aspers, 319-338. Oxford: Oxford University Press.

Stone, Jeffrey.C. 1995. A Short History of the Cartography of Africa. Lewiston, NY: Edwin Mellen Press.

Stretton, Grace. 1924. "Some Aspects of Medieval Travel: Notably Transport and Accommodation, with Special Reference to the Wardrobe Accounts of Henry Earl of Derby, 1390-1393 Alexander Prize, 1924.” Transactions of the Royal Historical Society 7: 77-97.

Sullivan, Robert. 2011. Geography Speaks: Performative Aspects of Geography. Burlington VT and London: Ashgate.

Towner, John. 1985. "The Grand Tour: A Key Phase in the History of Tourism." Annals of Tourism Research 12 (3): 297-333.

Urry, John. 1990. The Tourist Gaze: Leisure and Travel in Contemporary Societies. Sage Modern Politics Series. Thousand Oaks, CA: Sage.

- 2002. The Tourist Gaze. Published in Association with Theory, Culture \& Society. Thousand Oaks, CA: Sage.

Ventresca, Marc J., and John W. Mohr. 2002. "Archival Research Methods." In The Blackwell Companion to Organizations, edited by J. A. C. Baum, 805-828. Oxford: Wiley-Blackwell.

Wheeler, Valerie. 1986. "Travelers' Tales: Observations on the Travel Book and Ethnography." Anthropological Quarterly 59 (2): 52-63.

Zeithaml, Valerie. A., A. Parasuraman, and Leonard L. Berry. 1990. Delivering Quality Service: Balancing Customer Perceptions and Expectations. New York: Free Press.

Vasiliki Baka holds a Ph.D. in Information Systems from the Information Systems and Innovation Group, Department of Management, London School of Economics and Political Science and she is currently an assistant professor at the Technologies in Practice and Technology, Innovation Management \& Entrepreneurship Research Groups at the IT University of Copenhagen. She works at the intersection of organization, technology and society and her main research interests revolve around organizational reputation managing practices, place-making, process philosophy, digital innovation and most recently social collaboration platforms and their potential in developing countries. 